\title{
ॠUSGS
}

science for a changing world

\section{Suspended-Sediment Concentration and Pool Sedimentation Data for the Gibbon River, Yellowstone National Park, Wyoming, September 2000 through October 2001}

Open-File Report 03-185

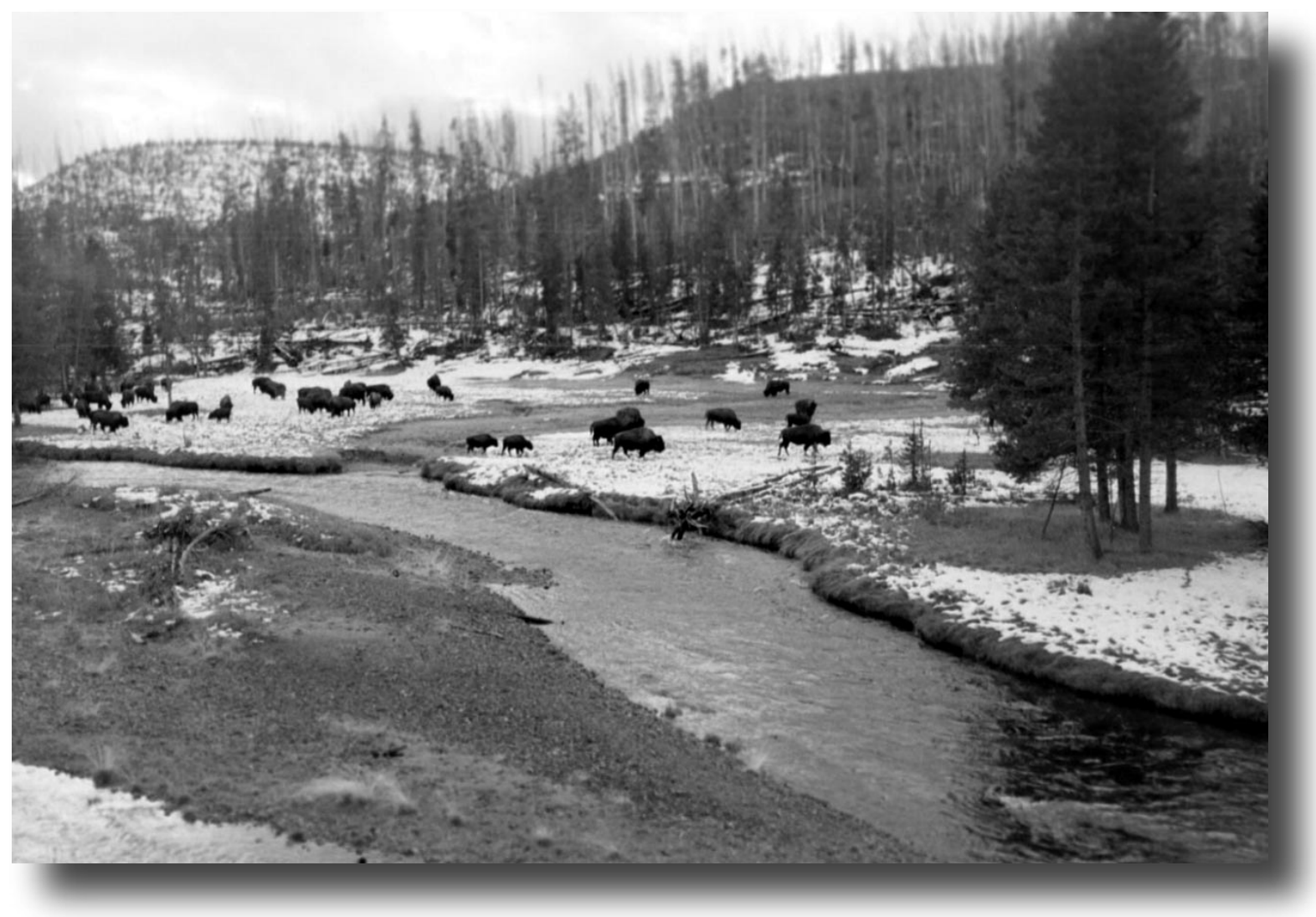

Prepared in cooperation with the 
U.S. Department of the Interior

U.S. Geological Survey

\section{Suspended-Sediment Concentration and Pool} Sedimentation Data for the Gibbon River, Yellowstone National Park, Wyoming, September 2000 through October 2001

By Peter R. Wright and Ronald B. Zelt

Open-File Report 03-185

Prepared in cooperation with the NATIONAL PARK SERVICE

Cheyenne, Wyoming 


\section{U.S. Department of the Interior}

GALE A. NORTON, Secretary

\section{U.S. Geological Survey}

Charles G. Groat, Director

Any use of trade, product, or firm names in this publication is for descriptive purposes only and does not imply endorsement by the U.S. Government

For additional information write to:

\section{District Chief}

U.S. Geological Survey, WRD

2617 E. Lincolnway, Suite B

Cheyenne, Wyoming 82001

Copies of this report can be purchased from:

\section{U.S. Geological Survey}

Branch of Information Services

Box 25286, Denver Federal Center

Denver, Colorado 80225 


\section{CONTENTS}

Page

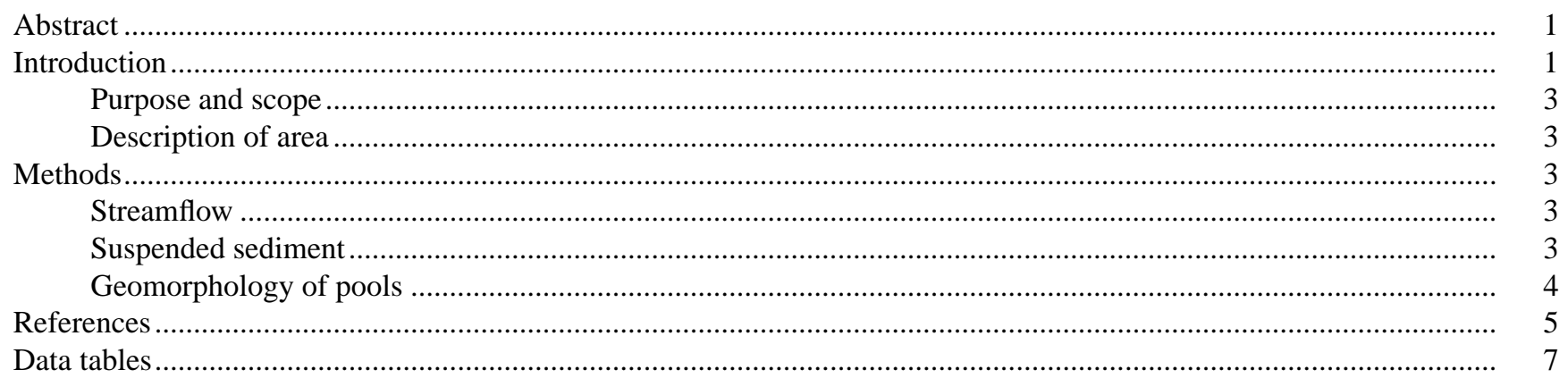

\section{Figures}

1. Location of streamflow-gaging stations, sediment-measurement sites, and pool study reach points along the Gibbon River, Yellowstone National Park, Wyoming....

\section{Tables}

1. Daily mean streamflow data for station 06037100, Gibbon River at Grand Loop Road Bridge at Madison Junction, Yellowstone National Park, Wyoming, March 23 through September 30, 2001

2. Streamflow measurements and width- and depth-integrated suspended-sediment data for the Gibbon River, September 14, 2000 through October 11, 2001

3. Suspended-sediment data for automatic-pumped samples collected at station 06036950, Gibbon River below Canyon Creek, near West Yellowstone, Montana, March 22 through June 28, 2001

4. Suspended-sediment data for automatic-pumped samples collected at station 06037100, Gibbon River at Grand Loop Road Bridge at Madison Junction, Yellowstone National Park, Wyoming, April 7 through June 28, 2001

5. Daily mean suspended-sediment concentrations and loads for station 06037100, Gibbon River at Grand Loop Road Bridge, at Madison Junction, Yellowstone National Park, Wyoming, April 1 through June 30, 2001

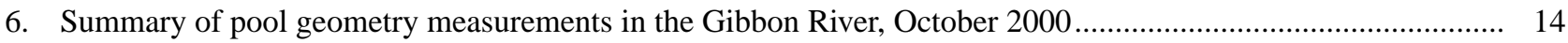

7. Particle-size distribution of fine bed sediment in pools, Gibbon River, October 2000 ......................................15

8. Particle-size distribution of surficial bed material in a riffle, Gibbon River, October 2000 .............................. 16 


\section{CONVERSION FACTORS, DATUMS AND ABBREVIATIONS}

\begin{tabular}{rcl}
\hline Multiply & By & To obtain \\
& Length & \\
foot (ft) & 0.3048 & meter $(\mathrm{m})$ \\
inch (in) & 2.54 & centimeter $(\mathrm{cm})$ \\
inch (in) & 25.40 & millimeter $(\mathrm{mm})$ \\
mile (mile) & 1.609 & kilometer $(\mathrm{km})$ \\
& Area & square kilometer $\left(\mathrm{km}^{2}\right)$ \\
square mile (mi $\left.{ }^{2}\right)$ & 2.590 & \\
& Load & kilogram per day \\
\hline
\end{tabular}

Temperature can be converted to degrees Fahrenheit $\left({ }^{\circ} \mathrm{F}\right)$ or degrees Celcius $\left({ }^{\circ} \mathrm{C}\right)$ as follows:

$$
\begin{aligned}
& { }^{\circ} \mathrm{F}=9 / 5\left({ }^{\circ} \mathrm{C}\right)+32 \\
& { }^{\circ} \mathrm{C}=5 / 9\left({ }^{\circ} \mathrm{F}-32\right)
\end{aligned}
$$

In this report, vertical coordinate information is referenced to the National Geodetic Vertical Datum of 1929 (NGVD of 1929); horizontal coordinate information is referenced to the North American Datum of 1927 (NAD 27).

$\begin{array}{ll}\text { Abbreviations used in this report: } \\ \mathrm{cm} & \text { centimeter } \\ \mathrm{ft}^{3} / \mathrm{s} & \text { cubic foot per second } \\ \mathrm{GCLAS} & \text { Graphical constituent loading analysis system } \\ \mathrm{m} & \text { meter } \\ \mathrm{m}^{2} & \text { square meter } \\ \mathrm{m}^{3} & \text { cubic meter } \\ \mathrm{m}^{3} / \mathrm{s} & \text { cubic meter per second } \\ \mathrm{mg} / \mathrm{L} & \text { milligrams per liter } \\ \mathrm{mm} & \text { millimeter } \\ \mu \mathrm{m} & \text { micrometer } \\ \mathrm{USGS} & \text { U.S. Geological Survey } \\ \text { YNP } & \text { Yellowstone National Park }\end{array}$




\title{
Suspended-Sediment Concentration and Pool Sedimentation Data for the Gibbon River, Yellowstone National Park, Wyoming, September 2000 through October 2001
}

\author{
By Peter R. Wright and Ronald B. Zelt
}

\begin{abstract}
This report presents data on streamflow, suspended-sediment concentration, geomorphic measurements of pools, and particle-size distribution of surficial bed material, collected along a 5-mile reach of the Gibbon River in Yellowstone National Park. The study was done in cooperation with the National Park Service. The Park Service was concerned about the potential effects that road reconstruction would have on water quality.

A streamflow-gaging station and two automatic pumping samplers were installed in September 2000 to collect suspended-sediment samples. The gage and samplers were operated seasonally from March through September 2001. The geomorphic survey of pools and sampling of bed material occurred during October 2000.
\end{abstract}

\section{INTRODUCTION}

The Gibbon River in Yellowstone National Park (YNP) (fig. 1) is an important trout fishery, featuring geothermally affected water in which fish and invertebrates are buffered against extremely low temperatures and ice formations (Varley and Schullery, 1983). In 1997, the Gibbon River ranked sixth in popularity among 73 streams and lakes fished in YNP (National Park Service, 1999). Several events in the Gibbon watershed since 1988 have individual or cumulative potential to increase sediment yields. The Gibbon River drainage was severely burned in the Greater Yellowstone fires of 1988 (Greater Yellowstone Coordinating Committee, 1989). Subsequent rain runoff produced debris flows that deposited large volumes of sediment and rock along and within the channel of the Gibbon River during 1989-91 (Meyer, 1993). Lastly, reconstruction and partial re-routing of the paved Park Service road along the Gibbon River commenced in the spring of 2001, which could represent a source of potential sediment erosion. Road reconstruction is planned to be completed in several phases over the following 4 to 6 years (National Park Service, 1999).

Deposition of fine sediment on the streambed can cause decreased survival of salmonid eggs and alevins by restricting flow and dissolved-oxygen distribution through streambed gravel, resulting in suffocation. Filling of pools with fine sediment deposits can reduce available habitat for benthic invertebrate communities that live on the surfaces of coarse substrate. Sedimentcaused turbidity decreases light penetration, which may inhibit primary production and disrupt food-chain energy transfer. Finally, increased turbidity adversely affects aesthetic values of streams, an important consideration for high-profile streams such as those in YNP.

Concerns about the potential effects that road reconstruction would have on water quality prompted the National Park Service and the U.S. Geological Survey (USGS) to enter into an agreement to characterize sediment conditions in the Gibbon River. The study was designed to: (1) document the mean daily suspended-sediment concentrations, fine bed-sediment size distribution in pools, and degree of pool sedimentation of the Gibbon River prior to the road reconstruction activity, (2) monitor conditions during the reconstruction period, and (3) compare the postconstruction conditions with the pre-construction baseline to evaluate any substantial changes. 


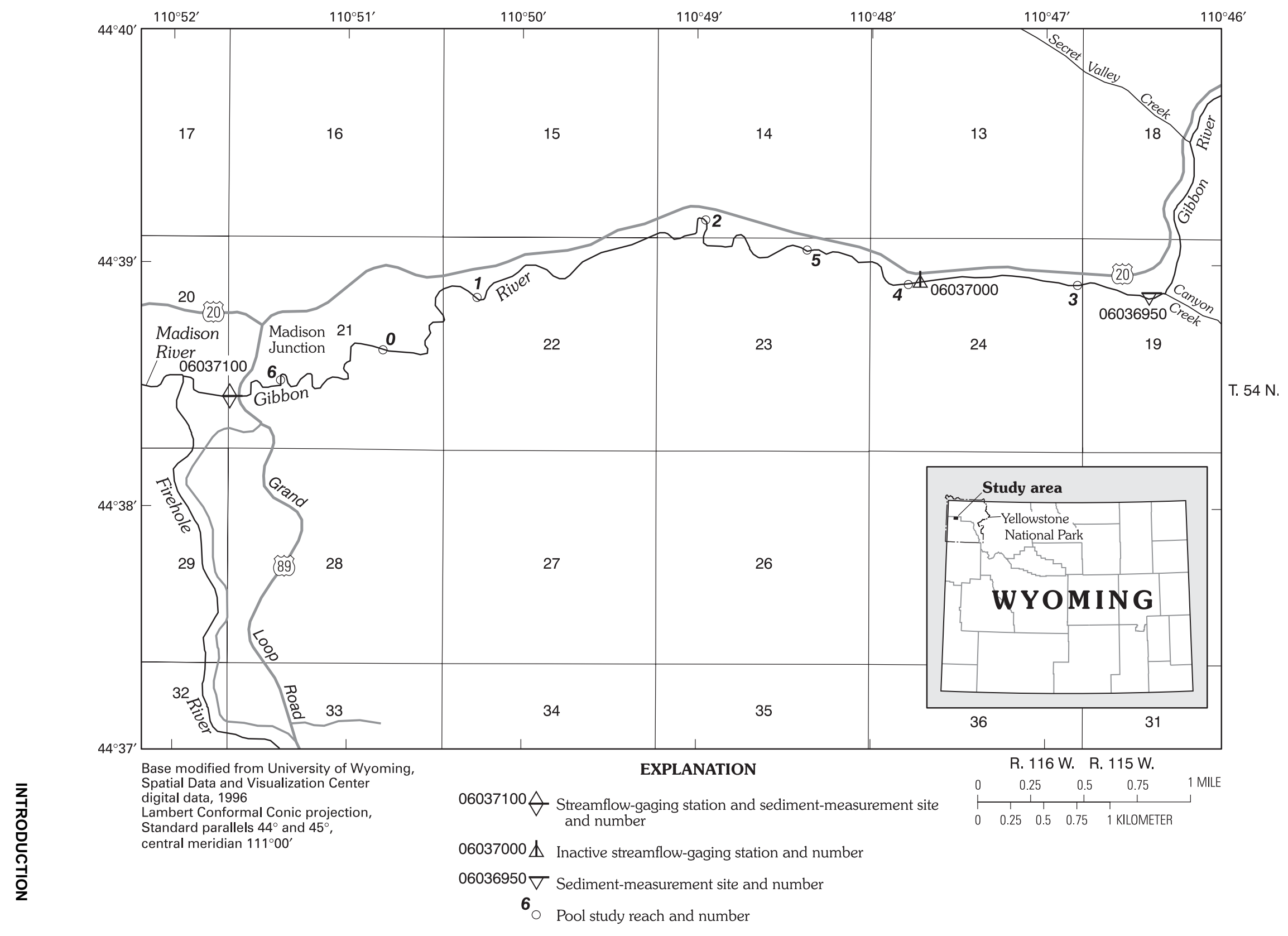

Figure 1. Location of streamflow-gaging stations, sediment-measurement sites, and pool study reach points along the Gibbon River, Yellowstone National Park, Wyoming. 


\section{Purpose and Scope}

The purpose of this report is to present the data collected during the first two seasons of this study (September 2000 through October 2001). Streamflow and suspended-sediment data are published here and as part of the Wyoming Water Resources Data Report for the 2001 water year (Swanson and others, 2002). Other data in this report include the geomorphic survey data for 16 pools, along with particle-size data for 18 samples of fine bed-sediment in pools. Methods of data collection and quality-assurance data are included in this report.

\section{Description of Area}

The Gibbon River originates at Grebe Lake at an elevation of $8023 \mathrm{ft}$ (feet) above NGVD of 1929 and flows 29 miles southwesterly to join the Firehole River at an elevation of $6798 \mathrm{ft}$. The upper river drains a high, mountainous area with small tributaries fed by snowmelt and cold springs. Middle reaches of the river receive tributary flows fed by snowmelt and cold springs (such as Solfatara Creek, Canyon Creek, and Secret Valley Creek), and effluent from geyser basins (Norris, Gibbon, and Monument) and hot springs (such as Sylvan, Beryl, and Iron). Soils are sandy, originating chiefly from glacial till or colluvium (National Park Service, 1999). Streambed materials are primarily volcanic rhyolite, with gravel constituting the largest size fraction (Vincent, 1967).

The snowmelt runoff period typically begins in mid-April, peaks by mid-June, and then declines rapidly until mid-July. During the remainder of the year, flows generally are low and relatively constant, although heavy rains and ensuing runoff events are not uncommon. The geyser and hot spring effluent contribute about 2 percent of total flow of the river during the snowmelt runoff period, and about 6 percent during low-flow conditions (Vincent, 1967). During the period from March 23, 2001 to October 11, 2001, the Gibbon River at Grand Loop Road Bridge had a maximum daily mean flow of $584 \mathrm{ft}^{3} / \mathrm{s}$ (cubic feet per second) on May 16 and a minimum daily mean flow of $79 \mathrm{ft}^{3} / \mathrm{s}$ on September 4. Daily mean sediment loads during this same period reached a maximum daily load of 596 tons/d (tons per day) on May 16 and a minimum daily load of 0.77 tons/d on June 27.

\section{METHODS}

The studied segment of the Gibbon River was based upon the area of road reconstruction. The study segment extends from the Gibbon Falls picnic area downstream to the Grand Loop Road Bridge at Madison Junction-a distance of about $5 \mathrm{mi}$. At the upper end of the study segment, which starts just below the mouth of Canyon Creek, a portable automatic waterquality sampler was installed. At the lower end of the study segment, a streamflow-gaging station and a portable automatic water-quality sampler were installed on the downstream side of the Grand Loop Road Bridge at Madison Junction (station 06037100). Within the study segment, 7 reaches were delineated for geomorphic pool surveys and 16 individual pool areas were identified for data collection.

\section{Streamflow}

Streamflow-gaging station 06037100 was installed in September 2000 and activated on March 20, 2001. It was operated until it was closed down for the coldweather season on October 11, 2001. Levels were surveyed to establish a datum for which relative gage heights could be reported. Streamflow was measured periodically to establish a stage-flow rating, and daily mean streamflow records were computed in accordance with standard USGS methods (Rantz and others, 1982). Daily streamflow records for the seasonal period of gage operation are presented in table 1 at the back of this report. Streamflow measurements are listed in table 2 at the back of this report.

\section{Suspended Sediment}

Two automatic pumping samplers were installed in the Gibbon River in September 2000. Each of these samplers, one just below the inflow of Canyon Creek (station 06036950) and the other at Madison Junction (station 06037100), were used to collect water samples that were analyzed for suspended-sediment concentration. The sampler immediately below the confluence of Canyon Creek was installed to attempt to detect possible effects of sediment inputs from debris torrents or erosion of debris fans that are not associated with road reconstruction. 
Both automatic samplers were operated using the same sampling frequency. The samplers were programmed to collect once-daily samples from March 22 through June 28, 2001. A subset of these samples representing every other day from April 13 through May 5, 2001 was sent for analysis. Samples for May 6 through May 13, 2001 were lost in transit. All daily samples for May 14 through June 28, 2001 were sent for analysis.

After the snowmelt runoff period had ended in June, the samplers were reprogrammed to collect storm runoff "event" samples. An "event" was defined as any flow magnitude within the upper 10 percent of the flowduration curve. The Gibbon River did not have any events large enough to reach the upper 10 percent of the duration curve so no "event" samples were collected.

Automatic samplers are efficient tools for the collection of water samples in remote areas or during short-duration events. However, these samples do not represent the "true" mean suspended-sediment concentration of the stream at the time of collection, because the sample is pumped from a single point in the cross section (Edwards and Glysson, 1999). To determine the "true" mean, a relation needs to be determined by comparing automatic point samples with depthintegrated, cross-sectional samples over the full range of flow (Edwards and Glysson, 1999). Depthintegrated, equal-width increment, cross-sectional samples (table 2) were collected concurrently with corresponding automatic point samples. Cross-sectional samples were collected in accordance with standard USGS protocols described by Edwards and Glysson (1999). These protocols are designed to provide discharge-weighted composite samples that best represent the mean suspended-sediment concentration across the entire cross section.

All samples submitted to the laboratory were analyzed for suspended-sediment concentration, and approximately 30 percent of those samples were analyzed for sand-silt distribution (percent less than 0.062-mm (millimter) diameter). Suspended-sediment concentration and particle-size distribution data for point samples collected at station 06036950 are presented in table 3, and for station 06037100 are presented in table 4. Samples were analyzed by the USGS sediment laboratory in Helena, Montana, in accordance with methods described in Guy (1969) and Lambing and Dodge (1993).
To determine the daily suspended-sediment load (suspended-sediment mass discharged over a 24-hour period), daily suspended-sediment concentrations from automatic samples and streamflow data were utilized with data from depth-integrated cross-sectional samples using the computer program "Graphical Constituent Loading Analysis System" (GCLAS) of the USGS (McKallip and others, 2001). Mean-daily suspendedsediment concentration and load data, calculated using GCLAS, are presented in table 5 for station 06037100 .

\section{Geomorphology of Pools}

Seven reaches of the Gibbon River distributed about evenly along the study segment between sediment-measurement sites (fig. 1) were selected for targeted geomorphic sampling. These reaches provided a suitable set of pools for monitoring finesediment deposition during low flow. The study reaches have gradients and pool spacing typical of pool-riffle or plane-bed channel types (Montgomery and Buffington, 1993). For the purposes of this study, pools were defined at low flow as areas of the channel with reduced velocity, little surface turbulence, deeper water than surrounding areas (Fitzpatrick and others, 1998), a distinct downstream terminus ("riffle crest"), and containing the channel thalweg (Lisle and Hilton, 1992). The residual pool is defined as the portion of the pool that is deeper than the hydraulic control (riffle crest) at the downstream end of the pool. In other words, the residual pool is the portion of the pool that would remain filled with water when the stream is barely flowing.

Within these 7 reaches, a total of 16 pools were measured and sampled in October 2000 using methods described by Hilton and Lisle (1993). Data were collected and used to determine the proportion of residual pool volume filled by fine sediment (Lisle and Hilton, 1992, 1999) during low flow. The fraction of residual pool volume filled with fine sediment $\left(V_{*}\right)$ is the ratio of fine-sediment volume $\left(V_{r f}\right)$ to the combined pool water and fine-sediment volume $\left(V_{r}\right)$ (Lisle and Hilton, 1992, 1999).

The calculation of $V *$ requires measurements of the water and fine-sediment volumes within the "residual" part of each pool. The first step in measuring each pool was to measure the riffle-crest depth. This was measured as the mean of several soundings in the thal- 
weg at the downstream terminus of each pool. The riffle crest depth was then used to physically determine the residual pool boundaries. For example, if a pool had a riffle crest depth of $10 \mathrm{~cm}$ (centimeters) then the residual pool boundary would be all areas of the pool that have a combined water/fine-sediment depth of $10 \mathrm{~cm}$ or greater.

Reach length and position of each pool relative to a reference station (reach point 0 ) were measured approximately along the stream centerline. Eleven to 25 soundings were made along a minimum of four transects across each pool, using a graduated steel rod $0.95 \mathrm{~cm}$ (0.375 in. (inch)) in diameter. Abrupt changes in resistance to penetration of the rod as it passed from sand or fine gravel to packed coarse gravel and cobbles indicated the base of the fine-sediment deposit.

Table 6 lists the results of the various geomorphic measurements of the 16 pools in the study segment. On the basis of these measurements, the volume-weighted mean proportion $\left(V_{*_{w}}\right)$ of the residual pool volumes filled with fine sediment was 14.9 percent.

From each of the measured pools, bed-material samples of the fine sediment overlying the gravel framework were collected. These samples were analyzed by Inberg-Miller Engineers in Cheyenne, Wyoming, to determine the size distribution of the fine bed sediments filling each pool. The results of these analyses are listed in table 7.

Samples of the fine bed sediments were collected using a 52-mm (2-in.) diameter pipe dredge with an attached sampling bag. The dredge sampler was used to collect a bulk composite sample of the residual pool fines from a minimum of three different sampling points in each pool. Two replicate samples of bed material were collected and analyzed for quality control.

Surficial bed material was sampled in one riffle as part of this study. This was accomplished using a pebble count (Wolman, 1954) of at least 100 particles along a tape or transverse line using $d_{\max }$ spacing (that is, the largest clast expected along the transect; see Bunte and Abt, 2001, p. 146-147). The intermediatediameter size class of each clast was measured using a US SA-97 hand-held particle-size analyzer (template). The particle-size distribution of the sampled riffle is listed in table 8 . The degree to which sampled particles larger than $6 \mathrm{~mm}$ were embedded in fine sediment was visually estimated for one-half of those sampled parti- cles (every second particle selected). Embeddedness data also are listed in table 8.

\section{REFERENCES}

Bunte, K. [I.], and Abt, S.R., 2001, Sampling surface and subsurface particle-size distributions in wadable graveland cobble-bed streams for analyses in sediment transport, hydraulics, and streambed monitoring: U.S. Department of Agriculture, Forest Service General Technical Report RMRS-GTR-74, 428 p.

Edwards, T.K., and Glysson, G.D., 1999, Field methods for measurement of fluvial sediment: U.S. Geological Survey Techniques of Water-Resources Investigations, book 3, chap. C2, 89 p.

Fitzpatrick, F.A., Waite, I.R., D'Arconte, P.J., Meador, M.R., Maupin, M.A., and Gurtz, M.E., 1998, Revised methods for characterizing stream habitat in the National Water-Quality Assessment Program: U.S. Geological Survey Water-Resources Investigations Report 984052, 67 p.

Greater Yellowstone Coordinating Committee, 1989, The Greater Yellowstone postfire assessment: Greater Yellowstone Coordinating Committee, Postfire Assessment Committee, $147 \mathrm{p}$.

Guy, H.P., 1969, Laboratory theory and methods for sediment analysis: U.S. Geological Survey Techniques of Water-Resources Investigations, book 5, chap. C1, 58 p.

Hilton, Sue, and Lisle, T.E., 1993, Measuring the fraction of pool volume filled with fine sediment: Albany, Calif., U.S. Forest Service Pacific Southwest Research Station Research Note PSW-RN-414, 11 p.

Lambing, J.H., and Dodge, K.A., 1993, Quality assurance for laboratory analysis of suspended-sediment samples by the U.S. Geological Survey in Montana: U.S. Geological Survey Open-File Report 93-131, 34 p.

Lisle, T.E., and Hilton, Sue, 1992, The volume of fine sediment in pools-An index of sediment supply in gravelbed streams: Water Resources Bulletin, v. 28, no. 2, p. 371-383.

1999, Fine bed material in pools of natural gravel bed channels: Water Resources Research, v. 35, p. 12911304.

McKallip, T.E., Koltun, G.F., Gray, J.R., and Glysson, G.D., 2001, GCLAS - A Graphical Constituent Loading Analysis System, in Proceedings of the Seventh Federal Interagency Sedimentation Conference, Reno, Nevada, March 25-29: Subcommittee on Sedimentation, v. II, p. VI-49 to VI-52. 
Meyer, G.A., 1993, Holocene and modern geomorphic response to forest fires and climate change in Yellowstone National Park: Albuquerque, University of New Mexico, unpublished Ph.D. dissertation, 402 p.

Montgomery, D.R., and Buffington, J.M., 1993, Channel classification, prediction of channel response, and assessment of channel condition: Washington State Timber/Fish/Wildlife Agreement, Report TFW-SH1093-002, $84 \mathrm{p}$.

National Park Service, 1999, Environmental assessmentMadison Junction/Norris Junction road improvement, Yellowstone National Park: Denver, Colo., National Park Service, 84 p.

Rantz, S.E., and others, 1982, Computation of discharge: U.S. Geological Survey Water-Supply Paper 2175, 2 v., $631 \mathrm{p}$.

Swanson, R.B., Woodruff, R.E., Laidlaw, G.A., Watson, K.R., and Clark, M.L., 2002, Water resources data, Wyoming, water year 2001; Volume 1. Surface water: U.S. Geological Survey Water-Data Report WY-01-1, 518 p. Online (downloadable pdf file) at $h t t p: / /$ wy.water.usgs.gov/pubs/adr/index.htm\#Water Year 2001.

Varley, J.D., and Schullery, P., 1983, Freshwater wilderness, Yellowstone fishes and their world: Yellowstone Library and Museum Association, Yellowstone National Park, 132 p.

Vincent, E.R., 1967, A comparison of riffle insect populations in the Gibbon River above and below the geyser basins, Yellowstone National Park: Limnology and Oceanography, v. 12, p. 18-26.

Wolman, M.G., 1954, A method of sampling coarse river bed material: AmericanGeophysical Union Trnsactions, v. 35, no. 6, p. 951-956. 


\section{DATA TABLES}


Table 1. Daily mean streamflow data for station 06037100, Gibbon River at Grand Loop Road Bridge at Madison Junction, Yellowstone National Park, Wyoming, March 23 through September 30, 2001

[MAX, maximum; MIN, minimum; AC-FT, acre-feet; --, no data]

LOCATION.--Latitude 44³8'26", longitude 11051'40", Teton County, Hydrologic Unit 10020007, Yellowstone National Park, on right bank, downstream side of bridge on highway 191-287, 0.2 miles upstream from the confluence with the Firehole River, 0.3 miles south of Madison Junction, and 14 miles east of West Yellowstone, Mont.

DRAINAGE AREA.--126 square miles.

GAGE.--Water-stage recorder. Elevation of gage is 6,800 ft above NGVD of 1929, from topographic map.

REMARKS.--Records fair. No regulation or diversions upstream from station. Streamflow measurement made on Oct. 12 during period station was not in operation was 138 cubic feet per second.

DISCHARGE, CUBIC FEET PER SECOND, WATER YEAR OCTOBER 2000 TO SEPTEMBER 2001

DAILY MEAN VALUES

\begin{tabular}{|c|c|c|c|c|c|c|c|c|c|c|c|c|}
\hline DAY & OCT & NOV & DEC & JAN & FEB & MAR & APR & MAY & JUN & JUL & AUG & SEP \\
\hline 1 & -- & -- & -- & -- & -- & -- & 103 & 261 & 159 & 112 & 93 & 84 \\
\hline 2 & -- & -- & -- & -- & -- & -- & 107 & 213 & 153 & 109 & 90 & 82 \\
\hline 3 & -- & -- & -- & -- & -- & -- & 103 & 189 & 154 & 108 & 88 & 81 \\
\hline 4 & -- & -- & -- & -- & -- & -- & 104 & 189 & 160 & 108 & 90 & 79 \\
\hline 5 & -- & -- & -- & -- & -- & -- & 103 & 210 & 155 & 111 & 89 & 84 \\
\hline 6 & -- & -- & -- & -- & -- & -- & 105 & 220 & 160 & 110 & 86 & 87 \\
\hline 7 & -- & -- & -- & -- & -- & -- & 105 & 210 & 148 & 111 & 87 & 86 \\
\hline 8 & -- & -- & -- & -- & -- & -- & 109 & 225 & 143 & 117 & 88 & 85 \\
\hline 9 & -- & -- & -- & -- & -- & -- & 102 & 260 & 139 & 122 & 88 & 82 \\
\hline 10 & -- & -- & -- & -- & -- & -- & 100 & 257 & 133 & 139 & 87 & 81 \\
\hline 11 & -- & -- & -- & -- & -- & -- & 98 & 249 & 128 & 124 & 87 & 80 \\
\hline 12 & -- & -- & -- & -- & -- & -- & 100 & 254 & 141 & 118 & 87 & 81 \\
\hline 13 & -- & -- & -- & -- & -- & -- & 101 & 264 & 153 & 113 & 88 & 84 \\
\hline 14 & -- & -- & -- & -- & -- & -- & 99 & 262 & 166 & 114 & 95 & 86 \\
\hline 15 & -- & -- & -- & -- & -- & -- & 92 & 326 & 182 & 118 & 97 & 86 \\
\hline 16 & -- & -- & -- & -- & -- & -- & 94 & 584 & 145 & 121 & 92 & 85 \\
\hline 17 & -- & -- & -- & -- & -- & -- & 101 & 425 & 131 & 114 & 92 & 86 \\
\hline 18 & -- & -- & -- & -- & -- & -- & 121 & 323 & 129 & 109 & 90 & 84 \\
\hline 19 & -- & -- & -- & -- & -- & -- & 143 & 276 & 127 & 107 & 88 & 84 \\
\hline 20 & -- & -- & -- & -- & -- & -- & 142 & 248 & 125 & 105 & 87 & 83 \\
\hline 21 & -- & -- & -- & -- & -- & -- & 140 & 228 & 122 & 103 & 88 & 81 \\
\hline 22 & -- & -- & -- & -- & -- & -- & 131 & 214 & 120 & 102 & 88 & 81 \\
\hline 23 & -- & -- & -- & -- & -- & 99 & 127 & 202 & 119 & 101 & 87 & 81 \\
\hline 24 & -- & -- & -- & -- & -- & 102 & 125 & 190 & 117 & 99 & 85 & 80 \\
\hline 25 & -- & -- & -- & -- & -- & 104 & 144 & 183 & 116 & 98 & 85 & 80 \\
\hline 26 & -- & -- & -- & -- & -- & 103 & 165 & 190 & 116 & 97 & 84 & 81 \\
\hline 27 & -- & -- & -- & -- & -- & 102 & 201 & 180 & 116 & 96 & 83 & 81 \\
\hline 28 & -- & -- & -- & -- & -- & 103 & 227 & 201 & 114 & 96 & 83 & 81 \\
\hline 29 & -- & -- & -- & -- & -- & 104 & 259 & 236 & 114 & 94 & 83 & 82 \\
\hline 30 & -- & -- & -- & -- & -- & 106 & 235 & 179 & 113 & 95 & 82 & 81 \\
\hline 31 & -- & -- & -- & -- & -- & 99 & -- & 165 & -- & 93 & 83 & -- \\
\hline TOTAL & -- & -- & -- & -- & -- & 922 & 3,886 & 7,613 & 4,098 & 3,364 & 2,720 & 2,479 \\
\hline MEAN & -- & -- & -- & -- & -- & 102 & 130 & 246 & 137 & 109 & 87.7 & 82.6 \\
\hline MAX & -- & -- & -- & -- & -- & 106 & 259 & 584 & 182 & 139 & 97 & 87 \\
\hline MIN & -- & -- & -- & -- & -- & 99 & 92 & 165 & 113 & 93 & 82 & 79 \\
\hline AC-FT & -- & -- & -- & -- & -- & 1,830 & 7,710 & 15,100 & 8,130 & 6,670 & 5,400 & 4,920 \\
\hline
\end{tabular}


Table 2. Streamflow measurements and width-and depth-integrated suspended-sediment data for the Gibbon River, September 14, 2000 through October 11, 2001

[ft, feet; $\mathrm{ft}^{3} / \mathrm{sec}$, cubic feet per second; Conc., suspended-sediment concentration; $\mathrm{mg} / \mathrm{L}$, milligrams per liter; mm, millimeter; --, no data]

\begin{tabular}{|c|c|c|c|c|c|c|c|c|c|}
\hline Date & Time & $\begin{array}{c}\text { Streamflow, } \\
\text { instantaneous } \\
\left(\mathrm{ft}^{3} / \mathrm{sec}\right)\end{array}$ & $\begin{array}{l}\text { Conc. } \\
(\mathrm{mg} / \mathrm{L})\end{array}$ & $\begin{array}{c}\text { Percent } \\
\text { finer than } \\
0.062 \mathrm{~mm} \\
\end{array}$ & Time & $\begin{array}{c}\text { Gage } \\
\text { height } \\
\text { (ft) } \\
\end{array}$ & $\begin{array}{c}\text { Streamflow, } \\
\text { instantaneous } \\
\left(\mathrm{ft}^{3} / \mathrm{sec}\right)\end{array}$ & $\begin{array}{l}\text { Conc. } \\
(\mathrm{mg} / \mathrm{L})\end{array}$ & $\begin{array}{c}\text { Percent } \\
\text { finer than } \\
0.062 \mathrm{~mm} \\
\end{array}$ \\
\hline & \multicolumn{4}{|c|}{$\begin{array}{c}06036950 \text { - Gibbon River below Canyon Creek near West } \\
\text { Yellowstone, Montana }\end{array}$} & \multicolumn{5}{|c|}{$\begin{array}{l}06037100 \text { - Gibbon River at Grand Loop Road at Bridge Madison } \\
\text { Junction, Yellowstone National Park, Wyoming }\end{array}$} \\
\hline $09-14-00$ & 1225 & 85 & 5 & -- & 1445 & 4.09 & 105 & 4 & -- \\
\hline $09-27-00$ & 1600 & 85 & 9 & 90 & 1700 & 4.10 & 100 & 21 & 54 \\
\hline $10-12-00$ & -- & -- & -- & -- & 1030 & 4.18 & 138 & $6,{ }^{1} 5$ & -- \\
\hline $10-15-00$ & 1500 & 96 & $3,{ }^{1} 3$ & -- & -- & -- & -- & -- & -- \\
\hline 03-22-01 & 1730 & 89 & 10 & -- & 1500 & 4.06 & 107 & 10 & -- \\
\hline 05-14-01 & 2002 & -- & 16 & 83 & 1602 & 4.69 & 274 & 28 & 77 \\
\hline 05-14-01 & 2004 & -- & 17 & 79 & 1604 & 4.69 & 274 & 21 & 80 \\
\hline 05-14-01 & 2006 & -- & 17 & 79 & 1606 & 4.69 & 274 & 30 & 50 \\
\hline $05-18-01$ & 1002 & 324 & 23 & 67 & 0902 & 4.95 & 331 & 33 & 80 \\
\hline 05-18-01 & 1004 & 324 & 19 & 72 & 0904 & 4.95 & 331 & 23 & 75 \\
\hline 05-18-01 & 1006 & 324 & 21 & 70 & 0906 & 4.95 & 331 & 30 & 51 \\
\hline 06-05-01 & 1302 & 154 & 5 & 93 & 1102 & 4.28 & 149 & 6 & 87 \\
\hline 06-05-01 & 1304 & 154 & 5 & 85 & 1104 & 4.28 & 149 & 6 & 88 \\
\hline 06-05-01 & 1306 & 154 & 4 & 62 & 1106 & 4.28 & 149 & 5 & 78 \\
\hline $06-28-01$ & 1600 & 94 & -- & -- & 1400 & 4.11 & 110 & -- & -- \\
\hline 08-13-01 & -- & -- & -- & -- & 1530 & 4.01 & 86 & -- & -- \\
\hline $10-11-01$ & 1301 & 69 & 26 & 57 & 1001 & 4.00 & 88 & 12 & 58 \\
\hline $10-11-01$ & 1302 & 69 & 4 & -- & 1002 & 4.00 & 88 & 2 & -- \\
\hline $10-11-01$ & ${ }^{2} 1303$ & -- & -- & -- & 1003 & 4.00 & 88 & 2 & 80 \\
\hline 10-11-01 & 1304 & 69 & 4 & -- & 1004 & 4.00 & 88 & 2 & -- \\
\hline $10-11-01$ & ${ }^{2} 1305$ & -- & -- & -- & 1005 & 4.00 & 88 & -- & 78 \\
\hline $10-11-01$ & 1306 & 69 & 5 & -- & 1006 & 4.00 & 88 & -- & -- \\
\hline $10-11-01$ & 1307 & 69 & 2 & 91 & 1007 & 4.00 & 88 & -- & 78 \\
\hline
\end{tabular}

${ }^{1}$ Replicate sample.

${ }^{2}$ Samples lost in transit. 
Table 3. Suspended-sediment data for automatic-pumped samples collected at station 06036950, Gibbon River below Canyon Creek, near West Yellowstone, Montana, March 22 through June 28, 2001

[These data represent suspended-sediment concentrations of instantaneous point samples collected using an automatic pumping sampler. Conc., concentration; mg/L, milligrams per liter; mm, millimeter; --, no data]

\begin{tabular}{|c|c|c|c|c|c|c|c|c|c|c|c|c|}
\hline Day & Time & $\begin{array}{l}\text { Conc. } \\
\text { (mg/L) }\end{array}$ & $\begin{array}{c}\text { Percent } \\
\text { finer than } \\
0.062 \mathrm{~mm}\end{array}$ & Time & $\begin{array}{l}\text { Conc. } \\
\text { (mg/L) }\end{array}$ & 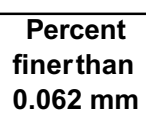 & Time & $\begin{array}{l}\text { Conc. } \\
\text { (mg/L) }\end{array}$ & $\begin{array}{c}\text { Percent } \\
\text { finerthan } \\
0.062 \mathrm{~mm}\end{array}$ & Time & $\begin{array}{l}\text { Conc. } \\
\text { (mg/L) }\end{array}$ & $\begin{array}{c}\text { Percent } \\
\text { finer than } \\
0.062 \mathrm{~mm}\end{array}$ \\
\hline & \multicolumn{3}{|c|}{ March } & \multicolumn{3}{|c|}{ April } & \multicolumn{3}{|c|}{ May } & \multicolumn{3}{|c|}{ June } \\
\hline 1 & -- & -- & -- & 1900 & 11 & -- & 1900 & 126 & -- & 1200 & 28 & -- \\
\hline 2 & -- & -- & -- & -- & -- & -- & & -- & -- & 1200 & 19 & 85 \\
\hline 3 & -- & -- & -- & 1900 & 14 & -- & 1900 & 141 & -- & 1200 & 32 & -- \\
\hline 4 & -- & -- & -- & -- & -- & -- & & -- & -- & 1200 & 18 & -- \\
\hline 5 & -- & -- & -- & 1900 & 13 & 70 & 1900 & 36 & 75 & 1200 & 14 & 48 \\
\hline 6 & -- & -- & -- & -- & -- & -- & -- & -- & -- & 1200 & 11 & -- \\
\hline 7 & -- & -- & -- & 1900 & 9 & -- & -- & -- & -- & 1200 & 11 & 81 \\
\hline 8 & -- & -- & -- & -- & -- & -- & -- & -- & -- & 1200 & 14 & -- \\
\hline 9 & -- & -- & -- & 1900 & 13 & -- & -- & -- & -- & 1200 & 11 & -- \\
\hline 10 & -- & -- & -- & -- & -- & -- & -- & -- & -- & 1200 & 13 & 72 \\
\hline 11 & -- & -- & -- & 1900 & 13 & 80 & -- & -- & -- & 1200 & 15 & -- \\
\hline 12 & -- & -- & -- & -- & -- & -- & -- & -- & -- & 1200 & 13 & -- \\
\hline 13 & -- & -- & -- & 1900 & 18 & -- & -- & -- & -- & 1200 & 7 & 91 \\
\hline 14 & -- & -- & -- & -- & -- & -- & 2000 & 1922 & -- & 1200 & 19 & -- \\
\hline 15 & -- & -- & -- & 1900 & 17 & -- & 2000 & 1115 & 5 & 1200 & 31 & -- \\
\hline 16 & -- & -- & -- & -- & -- & & 2000 & 733 & -- & 1200 & 13 & 82 \\
\hline 17 & -- & -- & -- & 1900 & 66 & 87 & 2000 & 183 & -- & 1200 & 11 & -- \\
\hline 18 & -- & -- & -- & -- & -- & -- & 2000 & 60 & -- & 1200 & 9 & -- \\
\hline 19 & -- & -- & -- & 1900 & 27 & -- & 1200 & 38 & -- & 1200 & 10 & 70 \\
\hline 20 & -- & -- & -- & -- & -- & -- & 1200 & 38 & -- & 1200 & 12 & -- \\
\hline 21 & -- & -- & -- & 1900 & 29 & -- & 1200 & 25 & 70 & 1200 & 12 & -- \\
\hline 22 & 1900 & 11 & -- & -- & -- & -- & 1200 & 37 & -- & 1200 & 10 & 75 \\
\hline 23 & -- & -- & -- & 1900 & 29 & 86 & 1200 & 35 & -- & 1200 & 12 & -- \\
\hline 24 & 1900 & 13 & 79 & -- & -- & -- & 1200 & 23 & 70 & 1200 & 13 & -- \\
\hline 25 & -- & -- & -- & 1900 & 102 & -- & 1200 & 25 & -- & 1200 & 13 & 55 \\
\hline 26 & 1900 & 13 & -- & -- & -- & -- & 1200 & 26 & -- & 1200 & 9 & -- \\
\hline 27 & -- & -- & -- & 1900 & 201 & -- & 1200 & 24 & 62 & 1200 & 17 & -- \\
\hline 28 & 1900 & 13 & -- & -- & -- & -- & 1200 & 50 & -- & 1200 & 17 & 40 \\
\hline 29 & -- & -- & -- & 1900 & 117 & 67 & 1200 & 76 & -- & -- & -- & -- \\
\hline 30 & 1900 & 12 & 88 & -- & -- & -- & 1200 & 28 & 64 & -- & -- & -- \\
\hline 31 & -- & -- & -- & -- & -- & -- & 1200 & 26 & -- & -- & -- & -- \\
\hline
\end{tabular}


Table 4. Suspended-sediment data for automatic-pumped samples collected at station 06037100, Gibbon River at Grand Loop Road Bridge at Madison Junction, Yellowstone National Park, Wyoming, April 7 through June 28, 2001

[These data represent suspended-sediment concentrations of instantaneous point samples collected using an automatic pumping sampler. Conc., concentration; $\mathrm{mg} / \mathrm{L}$, milligrams per liter; $\mathrm{mm}$, millimeter; --, no data]

\begin{tabular}{|c|c|c|c|c|c|c|c|c|c|c|c|c|}
\hline Day & Time & $\begin{array}{l}\text { Conc. } \\
\text { (mg/L) }\end{array}$ & $\begin{array}{l}\text { Percent } \\
\text { finer than } \\
0.062 \mathrm{~mm}\end{array}$ & Time & $\begin{array}{l}\text { Conc. } \\
\text { (mg/L) }\end{array}$ & $\begin{array}{l}\text { Percent } \\
\text { finer than } \\
0.062 \mathrm{~mm}\end{array}$ & Time & $\begin{array}{l}\text { Conc. } \\
\text { (mg/L) }\end{array}$ & $\begin{array}{c}\text { Percent } \\
\text { finer than } \\
0.062 \mathrm{~mm}\end{array}$ & Time & $\begin{array}{l}\text { Conc. } \\
\text { (mg/L) }\end{array}$ & $\begin{array}{c}\text { Percent } \\
\text { finer than } \\
0.062 \mathrm{~mm}\end{array}$ \\
\hline & \multicolumn{3}{|c|}{ March } & \multicolumn{3}{|c|}{ April } & \multicolumn{3}{|c|}{ May } & \multicolumn{3}{|c|}{ June } \\
\hline 1 & -- & -- & -- & -- & -- & -- & 1900 & 37 & -- & 1200 & 17 & 42 \\
\hline 2 & -- & -- & -- & -- & -- & -- & & -- & -- & 1200 & 18 & -- \\
\hline 3 & -- & -- & -- & -- & -- & -- & 1900 & 20 & -- & 1200 & 17 & -- \\
\hline 4 & -- & -- & -- & -- & -- & -- & & -- & -- & 1200 & 14 & 49 \\
\hline 5 & -- & -- & -- & -- & -- & -- & 1900 & 23 & 82 & -- & -- & -- \\
\hline 6 & -- & -- & -- & -- & -- & -- & -- & -- & -- & 1200 & 11 & -- \\
\hline 7 & -- & -- & -- & 1900 & 22 & -- & -- & -- & -- & 1200 & 14 & 51 \\
\hline 8 & -- & -- & -- & -- & -- & -- & -- & -- & -- & 1200 & 11 & -- \\
\hline 9 & -- & -- & -- & -- & -- & -- & -- & -- & -- & 1200 & 21 & -- \\
\hline 10 & -- & -- & -- & -- & -- & -- & -- & -- & -- & 1200 & 7 & 90 \\
\hline 11 & -- & -- & -- & -- & -- & -- & -- & -- & -- & 1200 & 10 & -- \\
\hline 12 & -- & -- & -- & -- & -- & -- & -- & -- & -- & 1200 & 9 & -- \\
\hline 13 & -- & -- & -- & 1900 & 14 & -- & -- & -- & -- & 1200 & 9 & 81 \\
\hline 14 & -- & -- & -- & -- & -- & -- & 1900 & 21 & -- & 1200 & 12 & -- \\
\hline 15 & -- & -- & -- & 1900 & 10 & 62 & 1900 & 83 & 81 & 1200 & 23 & -- \\
\hline 16 & -- & -- & -- & -- & -- & & 1900 & 1359 & -- & 1200 & 11 & 88 \\
\hline 17 & -- & -- & -- & -- & -- & -- & 1900 & 3510 & -- & 1200 & 10 & -- \\
\hline 18 & -- & -- & -- & -- & -- & -- & 1200 & 141 & -- & 1200 & 8 & -- \\
\hline 19 & -- & -- & -- & 1900 & 18 & -- & 1200 & 53 & -- & 1200 & 6 & 96 \\
\hline 20 & -- & -- & -- & -- & -- & -- & 1200 & 34 & 48 & 1200 & 15 & -- \\
\hline 21 & -- & -- & -- & 1900 & 19 & -- & 1200 & 34 & -- & 1200 & 8 & -- \\
\hline 22 & -- & -- & -- & -- & -- & -- & 1200 & 27 & -- & 1200 & 6 & 72 \\
\hline 23 & -- & -- & -- & 1900 & 18 & 84 & 1200 & 71 & 21 & 1200 & 12 & -- \\
\hline 24 & -- & -- & -- & -- & -- & -- & 1200 & 26 & -- & 1200 & 8 & -- \\
\hline 25 & -- & -- & -- & 1900 & 29 & -- & 1200 & 26 & -- & 1200 & 9 & 68 \\
\hline 26 & -- & -- & -- & -- & -- & -- & 1200 & 21 & 59 & 1200 & 6 & -- \\
\hline 27 & -- & -- & -- & 1900 & 49 & -- & 1200 & 18 & -- & 1200 & 4 & -- \\
\hline 28 & -- & -- & -- & -- & -- & -- & 1200 & 33 & -- & 1200 & 10 & 46 \\
\hline 29 & -- & -- & -- & 1900 & 34 & 85 & 1200 & 43 & 71 & -- & -- & -- \\
\hline 30 & -- & -- & -- & -- & -- & -- & 1200 & 21 & -- & -- & -- & -- \\
\hline 31 & -- & -- & -- & -- & -- & -- & 1200 & 13 & -- & -- & -- & -- \\
\hline
\end{tabular}


Table 5. Daily mean suspended-sediment concentrations and loads for station 06037100, Gibbon River at Grand Loop Road Bridge at Madison Junction, Yellowstone National Park, Wyoming, April 1 through June 30, 2001

[mg/L, milligrams per liter; tons/d, tons per day; e, estimated, --, no data]

\section{EXTREMES FOR PERIOD OF RECORD.--}

SEDIMENT CONCENTRATION: Maximum daily mean during period of operation, $360 \mathrm{mg} / \mathrm{L}$, May 16; minimum daily mean during period of operation, $2 \mathrm{mg} / \mathrm{L}$, June 27.

SEDIMENT LOADS: Maximum daily mean during period of operation, 596 tons/d, May 16; minimum daily mean during period of operation, 0.77 ton/d, June 27.

\begin{tabular}{|c|c|c|c|c|c|c|}
\hline Day & $\begin{array}{c}\text { Mean } \\
\text { concen- } \\
\text { tration } \\
(\mathrm{mg} / \mathrm{L})\end{array}$ & $\begin{array}{l}\text { Load } \\
\text { (tons/day) }\end{array}$ & $\begin{array}{c}\text { Mean } \\
\text { concen- } \\
\text { tration } \\
(\mathrm{mg} / \mathrm{L})\end{array}$ & $\begin{array}{c}\text { Load } \\
\text { (tons/day) }\end{array}$ & $\begin{array}{c}\text { Mean } \\
\text { concen- } \\
\text { tration } \\
\text { (mg/L) }\end{array}$ & $\begin{array}{l}\text { Load } \\
\text { (tons/day) }\end{array}$ \\
\hline & \multicolumn{2}{|c|}{ April } & \multicolumn{2}{|c|}{ May } & \multicolumn{2}{|c|}{ June } \\
\hline 1 & e12 & e3.3 & 41 & 29 & 8 & 3.4 \\
\hline 2 & e14 & e4.0 & e35 & e20 & 9 & 3.6 \\
\hline 3 & e16 & $\mathrm{e} 4.5$ & 26 & 13 & 8 & 3.4 \\
\hline 4 & e18 & $\mathrm{e} 5.1$ & e36 & e18 & 7 & 2.9 \\
\hline 5 & e20 & e5.6 & 32 & 18 & 5 & 2.2 \\
\hline 6 & e22 & e6.3 & e32 & e19 & 5 & 2.3 \\
\hline 7 & 24 & 6.9 & e38 & e22 & 6 & 2.6 \\
\hline 8 & e24 & e7.0 & e41 & e25 & 6 & 2.4 \\
\hline 9 & e22 & e6.1 & $\mathrm{e} 50$ & $\mathrm{e} 35$ & 9 & 3.3 \\
\hline 10 & e21 & e5.6 & $\mathrm{e} 52$ & e36 & 4 & 1.6 \\
\hline 11 & e19 & $\mathrm{e} 5.1$ & e36 & $\mathrm{e} 24$ & 5 & 1.6 \\
\hline 12 & e18 & e 4.8 & e24 & e17 & 5 & 2.0 \\
\hline 13 & 16 & 4.4 & e21 & e15 & 7 & 2.8 \\
\hline 14 & e14 & e3.8 & 24 & 17 & 9 & 4.3 \\
\hline 15 & 12 & 3.0 & 20 & 18 & 11 & 5.4 \\
\hline 16 & e13 & e3.3 & 360 & 596 & 6 & 2.3 \\
\hline 17 & e15 & e4.1 & 269 & 304 & 5 & 1.7 \\
\hline 18 & e17 & e5.7 & 50 & 45 & 4 & 1.4 \\
\hline 19 & 20 & 7.6 & 13 & 9.4 & 4 & 1.2 \\
\hline 20 & e21 & e8.0 & 10 & 6.8 & 6 & 2.1 \\
\hline 21 & 21 & 8.0 & 11 & 6.7 & 4 & 1.4 \\
\hline 22 & e21 & e7.5 & 12 & 7.0 & 3 & 1.1 \\
\hline 23 & 21 & 7.1 & 23 & 13 & 5 & 1.7 \\
\hline 24 & e25 & e8.3 & 13 & 6.7 & 4 & 1.3 \\
\hline 25 & 31 & 12 & 11 & 5.4 & 4 & 1.3 \\
\hline 26 & e41 & e18 & 9 & 4.6 & 3 & .94 \\
\hline 27 & 52 & 28 & 9 & 4.3 & 2 & .77 \\
\hline 28 & e49 & $\mathrm{e} 30$ & 13 & 6.9 & 5 & 1.5 \\
\hline 29 & 41 & 29 & 13 & 8.1 & e6 & e1.3 \\
\hline 30 & e 40 & e25 & 9 & 4.6 & e6 & e 1.3 \\
\hline 31 & -- & -- & 7 & 3.0 & -- & -- \\
\hline TOTAL & -- & 277.1 & -- & $1,357.5$ & -- & 65.11 \\
\hline
\end{tabular}


Table 6. Summary of pool geometry measurements in the Gibbon River, October 2000

$\left[V_{r f}\right.$, volume of fine sediment in residual pool; $V_{*}$, fraction of residual pool occupied by fine sediment; Max, maximum; $D_{r}$, residual pool depth; $D_{r c}$, depth of riffle crest; $V_{r}$ volume of residual pool (water plus sediment); $\mathrm{m}^{3}$, cubic meter; $W_{r}$, surface width of residual pool; $\mathrm{m}^{2}$, square meters; cm, centimeters; Std. Dev., standard deviation; C.V., coefficient of variation; $V_{*_{w}}$, volume weighted mean proportion; SE, standard error; --, not determined]

\begin{tabular}{cccccccccccc}
\hline $\begin{array}{c}\text { Reference } \\
\text { station }\end{array}$ & $\begin{array}{c}\text { Dist. } \\
(\mathbf{m})\end{array}$ & Reach & \multicolumn{1}{c}{$\boldsymbol{V}_{\boldsymbol{r f}}$} & $\boldsymbol{V}_{*}$ & $\begin{array}{c}\text { Max } \boldsymbol{D}_{\boldsymbol{r}} \\
(\mathbf{m})\end{array}$ & $\begin{array}{c}\text { Max } \boldsymbol{D}_{\boldsymbol{r}} \\
\boldsymbol{D}_{\boldsymbol{r c}}\end{array}$ & $\begin{array}{c}\boldsymbol{V}_{\boldsymbol{r}} \\
\left(\mathbf{m}^{\mathbf{3}}\right)\end{array}$ & $\begin{array}{c}\text { Mean } \boldsymbol{W}_{\boldsymbol{r}} \\
(\mathbf{m})\end{array}$ & $\begin{array}{c}\text { Pool } \\
\text { length } \\
(\mathbf{m})\end{array}$ & $\begin{array}{c}\text { Plan area } \\
\left(\mathbf{m}^{2}\right)\end{array}$ & $\begin{array}{c}\text { Mean } \boldsymbol{D}_{\boldsymbol{r}} \\
(\mathbf{c m})\end{array}$ \\
\hline 06036950 & 645 & 3 & 1.31 & 0.337 & 0.35 & 0.56 & 3.89 & 3.28 & 18 & 59.0 & 5.11 \\
06036950 & 726 & 3 & 4.31 & 0.091 & 0.65 & 1.69 & 47.3 & 23.4 & 25 & 585 & 22.4 \\
06037000 & 104 & 4 & 17.99 & 0.146 & 1.01 & 2.03 & 123 & 10.1 & 50 & 504 & 24.1 \\
06037000 & 967 & 5 & 1.02 & 0.068 & 0.65 & 1.08 & 15.0 & 3.80 & 20 & 76.0 & 20.4 \\
06037000 & 1058 & 5 & 32.25 & 0.196 & 0.60 & 1.50 & 164 & 10.7 & 75 & 800 & 21.2 \\
06037000 & 1903 & 2 & 1.70 & 0.085 & 0.36 & 0.71 & 20.1 & 6.60 & 22 & 145 & 12.9 \\
06037000 & 2104 & 2 & 3.93 & 0.262 & 0.28 & 0.44 & 15.0 & 6.92 & 35 & 242 & 7.24 \\
06037000 & 2329 & 2 & 1.13 & 0.126 & 0.32 & 0.51 & 8.96 & 3.62 & 26 & 94.1 & 8.26 \\
06037100 & -3798 & 1 & 4.64 & 0.080 & 0.94 & 1.49 & 58.3 & 6.42 & 25 & 161 & 36.8 \\
06037100 & -3354 & 1 & 15.92 & 0.098 & 0.83 & 3.32 & 163 & 11.2 & 42 & 472 & 35.4 \\
06037100 & -3163 & 1 & 11.02 & 0.254 & 0.62 & 0.83 & 43.3 & 10.8 & 24 & 259 & 17.6 \\
06037100 & -2648 & 0 & 17.28 & 0.095 & 0.78 & 1.90 & 183 & 7.96 & 65 & 517 & 36.8 \\
06037100 & -2472 & 0 & 6.43 & 0.254 & 0.78 & 1.44 & 25.3 & 7.71 & 19 & 146 & 16.0 \\
06037100 & -2423 & 0 & 16.91 & 0.291 & 0.63 & 1.21 & 58.2 & 8.42 & 30 & 253 & 22.9 \\
06037100 & -454 & 6 & 30.61 & 0.187 & 1.29 & 3.58 & 163 & 8.52 & 45 & 383 & 48.1 \\
06037100 & -192 & 6 & 15.74 & 0.119 & 1.00 & 1.85 & 132 & 6.06 & 41 & 248 & 51.6 \\
\hline
\end{tabular}

$V_{*_{w}}$ weighted mean

SE
0.149 (14.9 percent of residual pool volume occupied by fine sediment) 0.017 
Table 7. Particle-size distribution of fine bed sediment in pools, Gibbon River, October 2000

[Dist., distance from reference station (positive values indicate a downstream position; negative values indicate an usptream position); m, meter; mm, millimeter; $\mu \mathrm{m}$, micrometer; QC, quality-control replicate sample]

\begin{tabular}{|c|c|c|c|c|c|c|c|c|c|c|c|c|c|}
\hline \multirow{2}{*}{$\begin{array}{l}\text { Reference } \\
\text { station }\end{array}$} & \multirow{2}{*}{$\begin{array}{l}\text { Dist. } \\
\text { (m) }\end{array}$} & \multirow[b]{2}{*}{ Reach } & \multirow{2}{*}{$\begin{array}{c}\text { Date } \\
\text { sampled }\end{array}$} & \multicolumn{10}{|c|}{ Percentage finer than indicated sieve size } \\
\hline & & & & $51 \mathrm{~mm}$ & $25 \mathrm{~mm}$ & $12.5 \mathrm{~mm}$ & $4.75 \mathrm{~mm}$ & $2.36 \mathrm{~mm}$ & $1.18 \mathrm{~mm}$ & $600 \mu \mathrm{m}$ & $300 \mu \mathrm{m}$ & $150 \mu \mathrm{m}$ & $75 \mu \mathrm{m}$ \\
\hline 06036950 & 645 & 3 & $10-14-00$ & 100 & 100 & 99 & 95 & 82 & 52 & 26 & 8 & 3 & 1.0 \\
\hline 06036950 & 726 & 3 & $10-14-00$ & 100 & 100 & 98 & 94 & 74 & 53 & 38 & 22 & 5 & 1.0 \\
\hline 06037000 & 104 & 4 & $10-14-00$ & 100 & 100 & 100 & 98 & 80 & 43 & 11 & 2 & 1 & 0.2 \\
\hline 06037000 & 967 & 5 & $10-15-00$ & 100 & 100 & 98 & 89 & 56 & 20 & 6 & 2 & 0 & 0.1 \\
\hline 06037000 & 1058 & 5 & $10-15-00$ & 100 & 100 & 100 & 97 & 91 & 77 & 57 & 35 & 14 & 4.0 \\
\hline 06037000 & 1058 & 5 & $10-15-00$ & 100 & 100 & 100 & 98 & 87 & 67 & 32 & 9 & 3 & 1.0 \\
\hline 06037000 & 1903 & 2 & $10-13-00$ & 100 & 90 & 86 & 60 & 41 & 27 & 15 & 6 & 2 & 0.4 \\
\hline 06037000 & 2104 & 2 & $10-13-00$ & 100 & 97 & 88 & 73 & 62 & 51 & 30 & 9 & 2 & 0.5 \\
\hline 06037000 & 2104 & 2 & $10-15-00$ & 100 & 97 & 91 & 71 & 50 & 35 & 18 & 4 & 1 & 0.2 \\
\hline 06037000 & 2329 & 2 & $10-13-00$ & 100 & 100 & 97 & 82 & 53 & 30 & 15 & 6 & 2 & 0.6 \\
\hline 06037100 & -3798 & 1 & $10-13-00$ & 100 & 100 & 93 & 76 & 68 & 64 & 56 & 29 & 6 & 2.0 \\
\hline 06037100 & -3354 & 1 & $10-13-00$ & 100 & 100 & 99 & 95 & 82 & 66 & 38 & 15 & 4 & 1.0 \\
\hline 06037100 & -3163 & 1 & $10-13-00$ & 100 & 100 & 100 & 87 & 70 & 63 & 51 & 18 & 4 & 1.0 \\
\hline 06037100 & -2648 & 0 & $10-12-00$ & 100 & 100 & 87 & 82 & 66 & 43 & 27 & 12 & 3 & 1.0 \\
\hline 06037100 & -2472 & 0 & $10-12-00$ & 100 & 88 & 69 & 55 & 44 & 33 & 18 & 4 & 1 & 0.4 \\
\hline 06037100 & -2423 & 0 & $10-12-00$ & 100 & 100 & 99 & 89 & 69 & 46 & 17 & 6 & 2 & 0.7 \\
\hline 06037100 & -454 & 6 & $10-11-00$ & 100 & 100 & 99 & 93 & 78 & 59 & 28 & 7 & 1 & 0.5 \\
\hline 06037100 & -192 & 6 & $10-11-00$ & 100 & 100 & 99 & 88 & 70 & 49 & 16 & 2 & 1 & 0.5 \\
\hline
\end{tabular}


Table 8. Particle-size distribution of surficial bed material in a riffle, Gibbon River, October 2000

[Numbers in bold represent the visually estimated embeddedness of individual particles. Dist., downstream distance from reference station; $\mathrm{m}$, meter; $\mathrm{n}$, total number of particles in sample; mm, millimeter]

\begin{tabular}{|c|c|c|c|c|c|c|c|c|c|c|c|c|c|c|c|c|c|c|c|c|c|c|}
\hline Station & $\begin{array}{l}\text { Dist. } \\
\text { (m) }\end{array}$ & Riffle & $\begin{array}{c}\text { Date } \\
\text { sampled }\end{array}$ & $\mathbf{n}$ & 2 & 2.8 & 4 & 5.6 & 8 & 11.2 & 16 & 22.6 & 32 & 45 & 64 & 90 & 128 & 180 & 256 & 360 & 512 & Mean \\
\hline & & & & & \multicolumn{18}{|c|}{ Percentage finer than indicated particle size (mm) } \\
\hline \multirow[t]{2}{*}{06037000} & 2159 & D1.5 & $10-15-00$ & 101 & 1.0 & 1.0 & 3.0 & 7.9 & 7.9 & 12.9 & 14.9 & 17.8 & 20.8 & 24.8 & 37.6 & 55.4 & 71.3 & 84.2 & 92.1 & 99.0 & 100.0 & \\
\hline & & & & & \multicolumn{18}{|c|}{ Estimated percent embeddedness of particle of indicated size (mm) } \\
\hline $\begin{array}{l}\text { Mean for size } \\
\text { and class }\end{array}$ & & & & & & & & & & 50 & 65 & 55 & 50 & 37 & 44 & 38 & 45 & 48 & & & & 44 \\
\hline \multirow{13}{*}{$\begin{array}{c}\text { Number of } \\
\text { particles }\end{array}$} & & & & 47 & & & & & & 1 & 2 & 2 & 2 & 3 & 10 & 12 & 11 & 4 & & & & \\
\hline & & & & & & & & & & 50 & 30 & 60 & 50 & 10 & 10 & 40 & 30 & 40 & & & & \\
\hline & & & & & & & & & & & 100 & 50 & 50 & 60 & 50 & 60 & 90 & 30 & & & & \\
\hline & & & & & & & & & & & & & & 40 & 90 & 0 & 70 & 40 & & & & \\
\hline & & & & & & & & & & & & & & & 10 & 80 & 80 & 80 & & & & \\
\hline & & & & & & & & & & & & & & & 60 & 0 & 50 & & & & & \\
\hline & & & & & & & & & & & & & & & 40 & 20 & 10 & & & & & \\
\hline & & & & & & & & & & & & & & & 30 & 30 & 20 & & & & & \\
\hline & & & & & & & & & & & & & & & 60 & 20 & 40 & & & & & \\
\hline & & & & & & & & & & & & & & & 40 & 30 & 30 & & & & & \\
\hline & & & & & & & & & & & & & & & 50 & 80 & 50 & & & & & \\
\hline & & & & & & & & & & & & & & & & 50 & 20 & & & & & \\
\hline & & & & & & & & & & & & & & & & 40 & & & & & & \\
\hline
\end{tabular}

